\title{
PREPARING FOR TEACHING
}


To My Father 


\section{PREPARING FOR TEACHING}

ROBERT J. CARBINES

Head, Professional Studies Department Catholic College of Education, Sydney 
Copyright (C) Robert J. Carbines 1989
All rights reserved
No part of this publication
may be reproduced or transmitted
in any form or by any means
without permission

First published 1989 by

THE MACMILLAN COMPANY OF AUSTRALIA PTY LTD

107 Moray Street, South Melbourne 3205

6 Clarke Street, Crows Nest 2065

Associated companies and representatives

throughout the world

National Library of Australia

cataloguing in publication data

Carbines, Robert J.

Preparing for teaching.

ISBN 978-0-333-50131-3

ISBN 978-1-349-11079-7 (eBook)

DOI 10.1007/978-1-349-11079-7

1. Teaching - Australia. 2. Student teaching Australia. I. Title.

371.3’028’0994

Set in Times by

Vera-Reyes Inc., Philippines 


\section{Contents}

Foreword Jack Walton

vii

Acknowledgements

viii

Introduction

ix

1 Preparing for Employment

Employment Offers in the Public System

How do I get my First Job in a Non-State School?

2 The First Week

On Day One

Your First Day with the Children

Considering the Rest of the School Year

Establishing the Class Routine

Some Practical Hints for the Rest of the First Week

3 Preparing for Teaching

Developing the Teacher's Program

What Constitutes a Good Program? 28

Integration

Resources

4 Making the Program Work

Teaching Strategies $\quad 34$

Group Work 36

Individualizing Instruction - Is it Possible? 38

An Approach to Teaching by Inquiry 40

Co-operative Teaching 46

5 Classroom Management Revisited

Preventing the Problems 49

What the Research Says 51

A Common-Sense Approach 52

6 Teaching Children with Special Needs

The Slow Learner 54

The Talented Child $\quad 57$

Children of Non-English-Speaking Background 59 
7 Evaluating and Record Keeping What Should I Evaluate?

8 Teacher-Parent Involvement

Planning the Parent-Teacher Meeting 73

A Simulated Meeting $\quad 76$

Encouraging Parental Involvement $\quad 78$

9 Contributing at the Whole School Level 81

10 Casual Teaching - How To

How do I get Started? 87

Preparing the Survival Kit $\quad 87$

Arriving at the School $\quad 88$

In the Classroom $\quad 89$

After the Day's Teaching $\quad 89$

11 Professional Dilemmas 91

Concluding Remarks 94 


\section{Foreword}

This book is based on the sound experience of the author who has been both a successful primary school teacher and an excellent principal, well regarded by his colleagues and the Education Department for which he worked. Dr Carbines is at present Senior Lecturer in the Catholic College of Education, Sydney, and Head of the Department of Professional Studies, a position which, amongst other things, has given him the opportunity of reflecting upon his experiences in primary education. This reflection has been enhanced by both his tertiary teaching and research activities.

Whilst the book is illuminated by theoretical understandings, its message is essentially practical. It is a book that students, particularly in their last year at college, or beginning teachers will find particularly useful. Nothing appears to have been omitted. The sound suggestions in the first chapter relating to job application and interview are well worth noting.

Putting myself in the position of a beginning teacher, I believe that all the really important questions which would be of interest to me are answered somewhere or other in the 11 chapters of the book. The book is arranged very logically, as a glance at the list of contents indicates. The style is clear and to the point, and diagrammatic outlines have been provided where necessary. The warmth of the author's personality emerges in his concern for all engaged in the teaching process. Teaching emerges from this book not only as a professional activity but as a very human enterprise, involving not only other teachers but also the students and the parents. The emphasis on both parent involvement and participation is worth remarking upon. In fact, I would encourage parents as well as beginning teachers to read this book, not only because one chapter has been devoted to parents but also because they would find the rest of the book informative and interesting, particularly if their children are currently in primary schools.

Another interesting aspect of the book is that Dr Carbines has not forgotten the casual teacher. Certainly, those teachers who, for a variety of reasons, will not have full-time employment after they have left college, will find Chapter 10 extremely helpful.

The image of a teacher which arises from a reading of the various chapters is one of a person possessing both professional skills and human understanding. It is the image of a person whom one would like to teach one's own child. The point I am making is 
that this book is not just tips for teachers but is also an attempt to put before the reader the model of what a teacher should be. Hoyle's extended rather than restricted professional image is emphasised. As Chapter 9 emphasises, teachers must operate beyond the confines of their classrooms and make a contribution to whole-school policy.

This book fills a gap in our educational literature, and I am certain that it is going to be most successful. What I think will contribute to its success is that, as inferred elsewhere, Dr Carbines has been able to illuminate practice from a very sound background of both practice and theory.

Professor Jack Walton

Department of Curriculum Studies

University of New England

\section{Acknowledgements}

The author wishes to thank the following personnel for permitting the use of their material in this book:

Mr Ian MacDonald for his material on interviewing stages and techniques (pp. 5-6)

The Primary English Teachers' Association of New South Wales for the use of their material relating to procedures for effective group work in the classroom (pp. 39-40).

In addition, the author wishes to acknowledge the extensive advice and support offered by the staff of Catholic College of Education, Sydney, during the writing of this book. 


\section{Introduction}

Today's teachers are experiencing increasing pressures from all sectors of the educational and local community. Discussions of increased emphasis in the basic skills subjects and the reintroduction of selective high schools are forcing our educators to question carefully the fundamental values that underpin their professional practice - the combination of turbulent teaching times and financial constraints in a wide range of educational services has produced in many teachers considerable confusion about the purpose of education as well as their own role in the teaching process.

Despite the gloom portrayed, teachers with their characteristic creativity and resilience will continue to accept the challenge in a constructive and positive manner, and the result will be the enhancement of educational productivity.

Increasingly, schools will be expected to identify their unique characteristics, develop an appropriate profile and be prepared to engage in marketing the strengths of that profile within the educational market place. Such deliberations will only occur in an effective and efficient manner when teachers operate as a team which is founded upon a common vision and purpose. At both primary and high school levels, there is increasing evidence of such activity and, importantly, it occurs in consultation with members of the local community. The result is evidenced in an informed educational community of both teachers and parents who have been involved in the decision-making process and together are committed to a common educational vision. As the dollar for the educational vote diminishes and the call for teacher accountability increases, school communities will be expected to engage increasingly in a consultative process about a variety of educational matters relevant to particular school contexts.

The fulfilment of diverse teacher roles such as those outlined above is now a normal expectation of most educational communities in the latter twentieth century. While the essential role of most teachers still is located predominantly in the classroom, the expansion of the practitioner's role into other domains is now a reality. While instruction in the classroom is of major importance for teachers, the extension of relationships with others both within the school and broader educational community has become an integral component of every teacher's brief.

The various chapters within this book address not only the 
traditional teacher role in the classroom, but also the various role expectations at both the school/corporate level and the community level. The book's content is particularly for those teachers who are launching their professional careers and therefore has a strong practical orientation, with ideas not only for survival but also for ensuring a genuine contribution at the various levels within the school context.

Discussions with many beginning teachers reveal the complex and demanding expectations made of them during the early stages of their teaching career. Many teachers will encounter the traditional difficulties of classroom management soon after they begin their careers. Such problems are generally surmountable after limited daily experience in the classroom; however, problems of consulting and negotiating with informed parents and significant others in the educational community are not resolved as readily. Likewise, difficulties are often encountered in the total school environment, when teachers are expected to make significant educational/curriculum decisions, based on the identified characteristics of the local school context. Developing a clear understanding of school policy and procedures and methods for implementation are underpinned by well-refined interpersonal skills with colleagues, administators and parents. In a similar way, the actual planning and development of such policies and associated school curricula demand of new teachers a sophisticated and complex set of behaviours that many find difficult to master in a limited period of time. The author acknowledges these challenges and therefore addresses them throughout the text.

Including whole school and community teacher roles in the discussion is intended in no way to diminish the importance of the teacher's traditional instructional role in the classroom. Indeed, the diverse concerns of the teacher at the classroom level are addressed, from ideas on the first day to strategies for programming a team's work. Such issues are indeed preoccupations of the new teacher and are therefore systematically addressed throughout the book. While the text is organized around these three broad roles of the teacher, as Figure 1 portrays, the child should remain the centre of all deliberations.

The effective fulfilment of each of these roles should only be seen as a means to an end - the enhancement of the quality of each child's education. Many decisions made by teachers on a daily level in the classroom context have a direct and significant influence on each child's learning. Likewise, dialogue and decisions at the whole school and community level relate directly to the nature and quality of each child's education. The purpose of this book therefore is to ensure that, as teachers, we effectively fulfil the various roles for which we are responsible. In this way we 


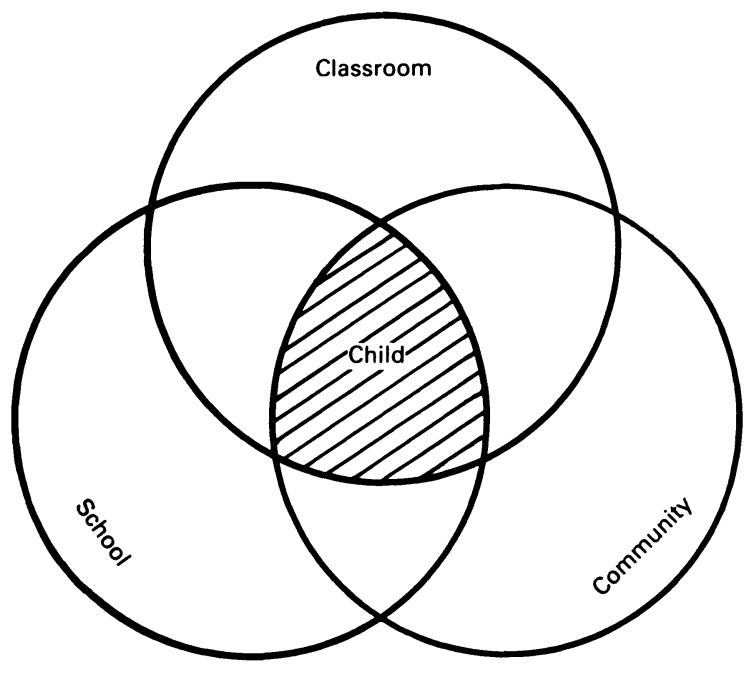

Figure 1 Diagram showing the central position of the child in teaching roles

can be confident that the education of tomorrow's citizens has been nurtured in a positive and constructive way. 